\title{
Além da sociedade de economia
} mista*

\section{Beyond public private corporation}

\author{
Luciano Ferraz**
}

\section{RESUMO}

O presente artigo analisa as parcerias societárias entre Estado e setor privado no Brasil, que transcendem as clássicas figuras do Decreto-Lei no 200/1967. O trabalho expõe que novas modelagens societárias podem ser conformadas, assumindo diferentes formas e estruturas. Dentro do contexto de governança coorporativa, o poder público está autorizado pelo ordenamento jurídico brasileiro a firmar acordos com acionistas privados que podem alterar a participação estatal na entidade, sua responsabilidade, a direção e os controles societários e uma série de outros fatores. Dependendo da modelagem societária, a entidade será exposta a diferentes níveis de incidência de normas de direito público e de direito privado e de controles públicos.

* Artigo recebido em 21 de outubro de 2013 e aprovado em 23 de outubro de 2013. Este artigo foi elaborado em homenagem à professora Maria Sylvia Zanella Di Pietro. Contou com a colaboração na pesquisa inicial do professor Vinícius Marins e, nas pesquisas subsequentes, na revisão e na formatação, da professora Bruna Corombarolli.

** Advogado. Mestre e doutor em direito administrativo (UFMG). Professor associado de direito administrativo na UFMG. Professor adjunto de direito financeiro e finanças públicas na PUCMinas. Universidade Federal de Minas Gerais, Belo Horizonte, Minas Gerais, Brasil. E-mail: ferrazadv@terra.com.br. 


\section{PALAVRAS-CHAVE}

Organização administrativa brasileira - administração indireta - empresas sob controle direto ou indireto do poder público - regime jurídico - participação do Estado em empresas privadas - implicações jurídicas - proposta de conciliação dos interesses públicos e privados: responsabilidade, direção, controles societários

\section{ABSTRACT}

The presente article investigates brazilian partnerships between businesses and Public Administration beyond the classics arrangements from Decreto-Lei 200/1967. It shows that those new arrangements can assume varied combinations, taking many forms and structures. Into the corporative governance context, government is allowed, according Brazilian legal system, to make agreements with private shareholders which can chance State participation in corporation's struture affecting its areas of responsibility, lines of authority and succession, and a variety of other factors can also be negotiated. Depending on the partnership structure, a partnership may be exposed to greater level public law or civil law and public reviews.

\section{KEY-WORDS}

Brazilian administrative organization - indirect administration - companies under direct or indirect control of the government - legal regime - state participation in private companies - legal implications - proposal for a reconciliation of public and private interests: responsibility, lines of authority and succession

\section{Objetivos do trabalho}

O escopo deste trabalho é avaliar a participação do Estado no setor empresarial, com luzes sobre parcerias com a iniciativa privada na constituição de sociedades que atuam nos domínios do mercado. ${ }^{1}$ Pretende-se ver alguns

\footnotetext{
1 Anoto que, adicionalmente à posição tradicional da doutrina brasileira, que subdivide a atuação empresarial do Estado nos domínios da exploração de atividades econômicas em sentido estrito (art. 173) e da prestação de serviços públicos (art. 175), ambas conformando atividades econômicas em sentido amplo, tenho sustentado - a partir de interpretação do
} 
dos diferentes formatos e meios dessa participação - e o que isso implica em termos de alteração de regime jurídico e da consectária submissão da entidade às normas derrogadoras do regime privado que lhes é típico.

O foco específico não haverá de ser as tradicionais sociedades de economia mista, entidades administrativas cujos contornos comparecem tratados, com certa uniformidade, nos manuais de direito administrativo. Pretende-se tratar das empresas subsidiárias e de outras sociedades privadas controladas direta ou indiretamente pelo poder público, além das "empresas participadas" - figuras que certamente clamam tratativa mais sistematizada no contexto da organização administrativa brasileira.

\section{Contexto geral das empresas estatais na administração pública brasileira}

O tema eleito insere-se no difícil capítulo das formatações organizacionais da administração pública com variantes significativas a depender da opção político-legislativa de cada país. ${ }^{2} \mathrm{E}$ o uso de variadas formas de atuação do Estado, consoante necessidades de cada tempo, leva ao reconhecimento de um "polimorfismo organizatório" da administração pública, tema trabalhado com propriedade em excertos doutrinários alienígenas. ${ }^{3}$

artigo 174 da Constituição - que a atuação do Estado nesse campo também pode se verificar no âmbito da atividade de fomento, do planejamento econômico (v.g., BNDES e Apex/Brasil) e da fiscalização (v.g., empresas de controle de trânsito). Também é de se ressaltar, no que toca à imprecisão da dicotomia (serviço público $\times$ atividade econômica), a cirúrgica anotação de Mário Engler Pinto Júnior, ao tratar dos mecanismos de supervisão das empresas do Estado: "A Coordenação em nível macroeconômico tornou-se muito mais complexa, na medida em que as empresas estatais deixaram de ter atuação meramente subsidiária da iniciativa privada e se tranformaram em concorrentes de peso nos mercados nacional e internacional" (PINTO JÚNIOR, Mário Engler. Empresa estatal: função econômica e dilemas societários. 2. ed. São Paulo: Atlas, 2013. p. 137).

2 Não apenas no Brasil, de modo geral o tema da organização administrativa tem sido examinado pela tradição jurídica. Na Alemanha, já em 1949, Ernst Fortshoff exortava a comunidade científica para o aprimoramento do estudo: "Das Behörden -und Organisationsrecht hat bisher in der festen und gesicherten Platz gefunden (...). Es entsprach dem bürgerlichen Rechtsstaat, dem es vorzüglich, um die gesetzliche Sicherung von Freiheit und dem Einzelnen interessiert war, während er den Bereich des Organisatorischen in höheren Grade in seiner bisherigen Ordnung beliess (...)" (FORSTHOFF, Ernst. Lehrbruch des Verwaltungsrecht. I Band. Munique: Beck, 1961. 8 Aufl., p. 375 a 378).

3 Dentre outros, v. MOREIRA, Vital. Administração autónoma e associações públicas. Coimbra: Almedina, 1997. p. 256. Em geral, no direito estrangeiro, tem prevalecido a ideia de "liberdade de formas" (formenwahlfreiheit) na organização administrativa, respeitados alguns limites, tais como a proibição do abuso de formas e a salvaguarda das vinculações jurídicas de 
Em linhas gerais, reconhece-se a existência de um contínuo processo de reformulação e de reconfiguração na estrutura orgânica das decisões da administração pública e da própria natureza de seu direito regulador.

Segundo diagnóstico de Paulo Otero, ${ }^{4}$ dita temática encontra-se permeada fundamentalmente por uma interpenetração do direito privado na operatividade do direito administrativo, com o recurso à formatação de figuras híbridas que não aceitam categorização nos tipos comuns das entidades públicas. ${ }^{5}$

No Brasil, por influência do Decreto-Lei no 200/1967, considerável parte dos estudos de direito administrativo manteve-se atrelada a uma concepção quadripartite das possíveis entidades de natureza administrativa, consoante o art. 5: autarquia, empresa pública, sociedade de economia mista e fundação pública. ${ }^{6}$ A tipicidade da organização administrativa tornou-se regra na abordagem do tema, cabendo às pessoas políticas adequarem-se aos moldes preconcebidos pelo legislador federal. ${ }^{7}$

Por outro lado, convém reconhecer que estruturas empresariais das quais o Estado brasileiro participa não se adequam plenamente aos modelos descritos no Decreto-Lei no 200/1967. E mais: as variantes de regime jurídico aplicável revelam também a existência entre nós do aludido "poliformismo organizatório" - que merece ser acudido nas particularidades, ao invés de nas generalidades, com destaque para desenhos da associação empresarial do

direito público e dos direitos fundamentais dos administrados. Na Alemanha, por exemplo, a Constituição de 1949 outorga ampla liberdade de conformação administrativa a cada um dos entes políticos (Bund, Lander e Gemeiden). As entidades locais (equivalentes aos nossos municípios), por exemplo, desenvolveram longa tradição no uso de formas privadas de administração. Ver SHOLZ, R. Kriterien für die Wahl der Rechtsform. Handbuch der Kommunalen Wissenschaft und Praxis. Springer Verlag, 8 Auf, p. 128 e ss. Prevalece por lá, contudo, a noção de que é necessária a presença do poder de influência da administração sobre a entidade criada (Einwirkungsplicht), independentemente da composição do capital.

4 OTERO, Paulo. Vinculação e liberdade de conformação do setor empresarial do Estado. Coimbra: Coimbra Editora, 1998. p. 225.

5 No Brasil, o polimorfismo organizatório é diversificado e comporta variação de enfoque. Não só porque existem entidades administrativas de um tipo, instituídas formalmente como se a outro tipo pertencessem, como também porque doutrina e jurisprudência reconhecem intercambiamento de regimes público e privado, em maior ou menor grau, a depender da atividade desenvolvida por cada uma delas.

6 Bem verdade que, a despeito da constitucionalização das noções de administração direta e indireta (v.g., art. 37. CR), a inclusão de novas entidades no âmbito desta última é matéria afeta à legislação infraconstitucional, como deixou ver a Lei no $11.107 / 2005$, que dispôs sobre os consórcios de direito público, determinando a inclusão dos consórcios de direito público no seio da administração indireta em todos os níveis.

7 Não se pode deixar de anotar que tal concepção foi recepcionada pela Constituição de 1988, ao acolher a classificação e os formatos previstos pelo Decreto-Lei nº 200/1967. 
poder público com particulares. ${ }^{8} \mathrm{O}$ anunciado "poliformismo organizatório", no contexto brasileiro, situa-se numa situação peculiar, a mixar situações de fato, consolidadas pela práxis, com posições jurídicas (rechtsposition), fincadas em tímidas tentativas de absorção normativa do fenômeno.

Não é despiciendo o alerta de que a junção de esforços de capitais públicos e privados no setor empresarial prontamente não constitui novidade, ${ }^{9}$ conquanto o formato a ensejar dita imbricação (com status institucional) tradicionalmente se tenha dado mercê das sociedades de economia mista - entidades criadas a partir de autorização legal específica (art. 37, XIX, da Constituição), sob a forma de sociedade anônima, de capital aberto ou fechado, e cuja maioria das ações com direito a voto pertence ao poder público ou a entidades de sua administração indireta (art. 5o, III, Decreto-Lei no ${ }^{\circ}$ 200/1967). ${ }^{10}$

Todavia, há situações em que os entes políticos ou as entidades de sua administração indireta obtêm participação acionária majoritária votante, equivalente ou minoritária em empresas de capital conjugado, exercendo, partilhando ou se submetendo ao controle decorrente da estrutura societária interna da entidade. ${ }^{11} \mathrm{E}$ nesse passo convém perquirir sobre o regime a que estarão submetidas, que certamente deverá ser menos rígido do que aquele aplicável, com diferentes graus de publicização, às sociedades de economia mista.

8 O problema não escapou à percepção, na Espanha, de Ariño Ortiz: “Es, ciertamente, un tema actual en esta encrucijada histórica de nuestro país (y de otros muchos, en Europa y América), pues no parece exagerado decir que, en esta materia, - papel del Estado en la economia y dimensión del sector empresarial público en una economia de mercado global - nos encontramos ante un cierto tournant de l'histoire". (ORTIZ, Gaspar Ariño. De la empresa publica a la empresa con participación pública. Revista de Administracion Publica, , n. 138, p. 8, 1995).

9 A união entre capital público e privado na exploração de atividades econômicas de interesse público não é nova, podendo-se identificar sua origem nas companhias colonizadoras do século XVII - empreendimentos para os quais Estado e iniciativa privada se aliaram com o objetivo de conquistar o Novo Mundo. Sobre o tema, cf. FERRAZ, Luciano. Principais apontamentos acerca das sociedades de economia mista. Revista do Tribunal de Contas de Portugal, Lisboa, n. 26, jul./dez. 1996.

10 Em alguns países, como na França, admite-se a possibilidade de empresas de economia mista minoritárias. Houve quem defendesse tal figura no direito brasileiro, sem acolhida da comunidade jurídica (v. CRETELLA JR., José. Dicionário de direito administrativo. Rio de Janeiro: Forense, 1978. p. 497).

11 A Lei Complementar no 101/2000 define empresa controlada como a "sociedade cuja maioria do capital com direito a voto pertença, direta ou indiretamente, a ente da Federação." (art. 2o, I) Estabelece, ainda, a categoria das empresas estatais dependentes: "empresa controlada que receba do ente controlador recursos financeiros para pagamento de despesas de pessoal ou de custeio em geral ou de capital, excluídos, no último caso, aqueles provenientes do aumento da participação acionária" (art. 2ํㅡㄴ, II). 
Nos próximos itens analisarei essas formas menos estudadas de conformação empresarial do Estado (entidades subsidiárias, sociedades controladas diretamente pelo poder público, sociedades controladas indiretamente pelo poder público e empresas participadas).

\section{1 Empresas subsidiárias}

O modelo das entidades subsidiárias tem previsão nas fontes no direito empresarial que regula a figura no art. 251 da Lei no 6.404/1976 (Lei das Sociedades Anônimas). Como tal compreende-se a companhia constituída mediante escritura pública, tendo como acionista único a sociedade brasileira, recebendo a denominação de subsidiária integral. ${ }^{12}$

A doutrina refere-se à subsidiária integral - única modalidade legalmente prevista com esse caráter - como hipótese intermediária entre a sociedade anônima e a sociedade unipessoal de responsabilidade limitada, hoje contemplada pelo nosso direito positivo (Lei no 12.441/2011). A subsidiária integral possui personalidade jurídica própria, de direito privado, que não se confunde com a personalidade de sua acionista única.

Na seara administrativa, não há uniformidade quanto aos contornos das sociedades subsidiárias, apresentando-se para parcela da doutrina como sinônimo de entidades controladas. ${ }^{13}$ Geralmente, admite-se que a entidade matriz detenha a totalidade do capital da subsidiária - hipótese de subsidiária integral; ou ainda, que a entidade matriz detenha apenas o controle societário, mas não a integralidade do capital, do que resulta entidade subsidiária parcial.

Exigência fundamental é que as subsidiárias possuam como objeto social atividade específica dentro do leque daquelas a que a empresa mãe se dedica; a criação da subsidiária, portanto, consistiria numa técnica de descentralização empresarial, adotada com o intuito de proporcionar maior especialização no desempenho de áreas determinadas que integram o objeto da empresa controladora.

2 CORRÊA-LIMA, Osmar Brina. Sociedade anônima. 3. ed. Belo Horizonte: Del Rey, 2005. p. 389.

13 É o caso de Marçal Justen Filho, para quem a empresa subsidiária é “aquela cujo controle acionário se encontra em poder de sociedade de economia mista ou empresa pública, a qual tem o poder de eleger a maioria dos administradores e determinar o destino societário. Tanto pode tratar-se de subsidiária integral como não, sendo o relevante o fenômeno do controle" (JUSTEN FILHO, Marçal. Comentários à Lei de Licitações e Contratos Administrativos. São Paulo: Dialética, 2009. p. 39). 
O texto constitucional refere-se, no art. 37, XX, às "subsidiárias das entidades mencionadas no inciso anterior" (autarquias, empresas públicas, sociedades de economia mista e fundações estatais) e no art. 173, § 1ㅇ (após a redação dada pela EC 19/1998) dispõe que “a lei estabelecerá o estatuto jurídico da empresa pública, da sociedade de economia mista e de suas subsidiárias...".

Tais dispositivos deixam ver que a subsidiária está ligada a uma entidade da administração indireta (como regra, porém não necessariamente, a empresas públicas e a sociedades de economia mista). A rigor, as subsidiárias são entidades controladas pelo poder público, a despeito de a legislação infraconstitucional frequentemente empregar as expressões - subsidiárias e controladas - de maneira apartada. ${ }^{14}$

Com efeito, em atenção à umbilical relação dessa figura societária com o direito empresarial, e, ainda, em decorrência das previsões legislativas reiteradas que contemplam concomitantemente entidades subsidiárias e entidades controladas, melhor seria compreender, pelas primeiras, apenas as subsidiárias integrais. As chamadas subsidiárias parciais, como se verá nos próximos tópicos, amoldar-se-iam ao conceito estrito (e não lato) de entidades controladas pelo poder público. ${ }^{15}$

O Supremo Tribunal Federal (STF), posicionando-se sobre o assunto, asseverou que as subsidiárias referidas na primeira parte do inciso $\mathrm{XX}$ do art. 37 , da $C R / 88$ são empresas privadas, que não integram a administração pública. ${ }^{16}$ No mesmo julgado, a Corte decidiu que a exigência da autorização

14 Uma das referências mais conhecidas está no art. 24, XIII, da Lei no 8.666/1993, que prevê a possibilidade de dispensa de licitação para "contratação realizada por empresa pública ou sociedade de economia mista com suas subsidiárias e controladas, para a aquisição ou alienação de bens, prestação ou obtenção de serviços, desde que o preço contratado seja compatível com o praticado no mercado". Para citar outros exemplos relevantes, confira-se art. 1ํ, parágrafo único, da mesma lei; art. 2º inciso II, da Lei de Responsabilidade Fiscal (Lei Complementar no 101, de 4.5.2000); arts. 116, 243 e 251 da Lei das Sociedades Anônimas (Lei no 6.404, de 15.12.1976); no art. 1.098 do Código Civil (Lei no 10.406, de 10.1.2002); e Constituição de 1988, no art. 37, incisos XVII, XIX, XX e §9‥ Fundamental assinalar que tais expressões variam de significado conforme o contexto normativo em que estejam inseridas. Ou seja, apresentam sentidos distintos em diferentes âmbitos, dependendo das finalidades das normas envolvidas.

15 Deve-se enfatizar que, nesses casos, o controle exercido pela entidade matriz é totalitário, segundo expressão de COMPARATO, Fábio Konder; SALOMÃO FILHO, Calixto. O poder de controle na sociedade anônima. 5. ed. Rio de Janeiro: Forense, 2008. p. 59.

16 STF - ADIMC 1649/DF, rel. min. Maurício Correia, DJU 8.9.2000. A decisão é acompanhada por notória doutrina do direito empresarial, que afirma: "A sociedade de economia mista que constitui uma subsidiária, ainda que integral, não terá, como já se demonstrou, criado uma economia mista de segundo grau; para tanto, seria necessário legislação atributiva do caráter de economia mista à subsidiária" (BORBA, José Edwaldo Tavares. Direito societário. 6. ed. Rio de Janeiro: Renovar, 2001. p. 451). Em síntese: a mera detenção de ações com direito a voto, por 
legislativa "em cada caso" não significa necessidade de "uma lei para cada subsidiária a ser criada". Para o STF, é bastante para suprir a exigência do art. 37, XX, a existência de dispositivo conferindo genericamente a autorização para criar subsidiárias na própria lei instituidora de determinada entidade da administração indireta. ${ }^{17}$

Quanto à exigência de que o pessoal permanente das subsidiárias das entidades da administração indireta seja contratado mediante concurso público, existe controvérsia. O entendimento predominante no TCU é o de que esses empregados estão a ele submetidos, ${ }^{18}$ conforme Súmula 231:

\section{A exigência de concurso público para admissão de pessoal se estende a toda a Administração Indireta, nela compreendidas as Autarquias, as Fundações instituídas e mantidas pelo Poder Público, as Sociedades de Economia Mista, as Empresas Públicas e, ainda, as demais entidades controladas direta ou indiretamente pela União, mesmo que visem a objetivos estritamente econômicos, em regime de competitividade com a iniciativa privada. ${ }^{19}$}

uma sociedade de economia mista, não confere à outra companhia - subsidiária - a mesma natureza jurídica da acionista, pois lhe falta o principal requisito, o da criação como tal por autorização legislativa específica, nos termos do art. 37, XIX, da Constituição da República. Para informação, esclarece-se que o anteprojeto de lei elaborado por comissão criada pelo Ministério do Planejamento, Orçamento e Gestão, mediante a Portaria no 426, de 6 de dezembro de 2007 - e integrada por ilustres juristas nacionais do quilate dos professores Almiro do Couto e Silva, Carlos Ari Sundfeld, Floriano de Azevedo Marques Neto, Maria Coeli Simões Pires, Maria Sylvia Zanella Di Pietro, Paulo Modesto, Sérgio de Andrea Ferreira - em seu art. 9o, estabelece que as subsidiárias integram a noção administração indireta e sujeitas ao respectivo regime jurídico. Além disso, nos termos do anteprojeto, as subsidiárias podem ser vinculadas a qualquer das modalidades de entidades da administração indireta. Nesse sentido, o §1ํ do art. 9 do anteprojeto fixa os tipos de subdiárias que cada entidade da administração direta pode ter: Art. 9․ As entidades estatais podem ter subsidiárias, que se integram à administração indireta, devendo sua instituição observar o disposto nos incisos XIX e XX do art. 37 da Constituição. §1ำ São subsidiárias: I - das autarquias, as empresas estatais, fundações estatais e autarquias por elas controladas; II - das empresas estatais, as empresas estatais e fundações estatais por elas controladas; III - das fundações estatais, as empresas estatais e fundações estatais por elas controladas.

17 De acordo com a ementa do julgado mencionado: "A lei criadora (da empresa estatal) é a própria medida autorizadora".

18 Esclareça-se que não há qualquer dispositivo constitucional ou legal que imponha uniformidade na realização de concursos públicos para a administração direta, autárquica e funcional, relativamente às empresas estatais, muito menos àquelas subsidiárias ou controladas. Nada impede que os critérios de seleção típicos do setor privado, desde que devidamente publicizados e com inscrições franqueadas a todos os interessados, possam ser, isonômica e transparentemente, aplicados.

19 Mas há um problema no verbete. O TCU termina por considerar as controladas como integrantes da administração indireta, o que é equivocado. Nesse sentido, ver Acórdão no $1.335 / 2004$, Plenário. 
Finalmente - e como fruto da interpretação do art. 37, XX, da CR/88 - defende-se que investimentos realizados pelas subsidiárias na aquisição de participação em outras empresas privadas não requerem autorização legislativa, diferentemente do que ocorre na hipótese de inversões feitas com o mesmo propósito por entidades da administração indireta. ${ }^{20}$

\subsection{Empresas controladas pelo poder público}

Seguindo a trilha do item anterior, é possível recorrer novamente ao direito empresarial para lograr uma concepção adequada a respeito do que se deve compreender por sociedades controladas diretamente pelo Poder Público e por sociedades controladas indiretamente pelo Poder Público, duas figuras pertencentes aos mesmos grupos (controladas) e com características semelhantes. Naturalmente, desse grupo estarão excluídas as sociedades de economia mista e as empresas públicas, porquanto objeto de disciplina legislativa específica, embora, grosso modo, constituam, ambas, também empresas controladas pelo Estado.

Preliminarmente, importa considerar que a palavra controle possui várias acepções, podendo significar vigilância, verificação, comando, regulação, direcionamento, constrangimento. ${ }^{21}$ No direito societário, emprega-se a expressão poder de controle como aptidão para comandar em última instância as atividades empresariais, impondo-lhe os rumos, diretivas e orientações.

Isso se extrai de análise perfunctória da Lei de Sociedades Anônimas, ao revelar a presença das expressões acionista controlador ${ }^{22}$ e sociedade controlada. ${ }^{23}$

20 Nesse sentido, veja-se o legado de Caio Tácito: “Os investimentos de subsidiárias em outras empresas, no país ou no exterior, são atos ordinários de administração, que prescindem de abono legislativo. Tão somente estarão alcançados pelo controle administrativo ou contábil que a supervisão ministerial ou o exame de contas possa propiciar" (TÁCITO, Caio. As empresas estatais no direito brasileiro. In: Temas de direito público. Rio de Janeiro: Renovar, 1997. v. 1, p. 686).

${ }^{21}$ Comparato e Salomão Filho, O poder de controle na sociedade anônima, op. cit., p. 37-40.

22 "Art. 116. Entende-se por acionista controlador a pessoa, natural ou jurídica, ou o grupo de pessoas vinculadas por acordo de voto, ou sob controle comum, que: a) é titular de direitos de sócio que lhe assegurem, de modo permanente, a maioria dos votos nas deliberações da assembleia geral e o poder de eleger a maioria dos administradores da companhia; e b) usa efetivamente seu poder para dirigir as atividades sociais e orientar o funcionamento dos órgãos da companhia".

23 "Art. 243. (...) §2º. Considera-se controlada a sociedade na qual a controladora, diretamente ou através de outras controladas, é titular de direitos de sócio que lhe assegurem, de modo permanente, preponderância nas deliberações sociais e o poder de eleger a maioria dos administradores". 
Das definições presentes na norma extrai-se que é "acionista controlador", ou sociedade controladora, a pessoa que seja titular de direitos de sócio que lhe assegurem preponderância nas deliberações da assembleia geral e poder de eleger a maioria dos administradores da companhia.

De se notar, contudo, que a conjunção empregada pelo legislador é aditiva e não alternativa, de modo que a união de ambos os direitos é pressuposto para a qualificação do poder de controle. Além disso, o controlador deve usufruir efetivamente de seu poder de controle sobre a empresa. E isso deve ser aplicado também ao controle estatal sobre as entidades. ${ }^{24}$

Mas o direito administrativo não trabalha nem reconhece outras modalidades de dominação societária, como o chamado controle minoritário ou compartilhado, nem tampouco a influência exercida sobre os destinos da organização empresarial pelo titular de ação de classe especial (golden share). ${ }^{25}$ E nesse particular encontra-se na contramão dos fatos e da lógica aplicada pelo mercado societário.

Com efeito, de acordo com o entendimento do TCU, a predominância formal do poder de controle (acionário apenas) da administração pública atrairá, com pequenas variações, a incidência parcial do regime jurídico administrativo, notadamente quanto às contratações (licitações e contratos), regime de admissão de pessoal e controles finalísticos. ${ }^{26}$

Como observa Mário Engler Pinto Júnior:

Diante da ausência de um pronunciamento inicisivo do Tribunal de Contas da União sobre o assunto, tem proliferado no cenário brasileiro o modelo de parceria societária, em que a maioria do capital votante da companhia investida pertence formalmente a algum veículo

24 O referido anteprojeto de lei de organização da administração pública brasileira, ao tratar das empresas estatais, buscou adequar os conceitos de empresas públicas e de sociedades de economia mista às normas do direito societário e compatibilizar o regime jurídico às exigências fixadas pelo texto constitucional. Desse modo, o caráter estatal das sociedades de economia mista não deve decorrer da titularidade da maioria do capital votante, nos termos do DecretoLei no 200/1967, mas da noção de controle estatal estável, que se caracteriza pela titularidade de direitos que asseguram, de modo permanente, preponderância nas deliberações ou poder de eleger a maioria dos administradores (SUNDFELD, Carlos Ari. Uma lei de normas gerais para organização administrativa brasileira: o regime jurídico comum das entidades estatais de direito privado. In: MODESTO, Paulo (Coord.). Nova organização administrativa brasileira. Estudos sobre a proposta da comissão de especialistas constituídas pelo Governo Federal para reforma da organização administrativa brasileira. 2. ed. Belo Horizonte: Fórum, 2010. p. 66-67).

25 Pinto Júnior, Empresa estatal, op. cit., p. 126.

26 TCU - ver Acórdão 243/2003, Plenário. 
de investimento privado (empresa ou fundo de investimento em participações), enquanto o controle acionário é verdadeiramente exercido de forma compartilhada com a empresa estatal que figura como acionista minoritária, ou até com preponderância decisória da segunda. Nesse caso, a aparência formal sobrepõe-se à realidade substancial para afastar a incidência das regras de direito público em relação à companhia investida, de modo a preservar a flexibilidade operacional e a afastar a interferência desconfortável dos órgãos de controle típicos do setor público. ${ }^{27}$

Em nota de rodapé, o mesmo autor assevera que no âmbito do TCU "não se conhece nenhuma decisão que tenha abordado expressamente a situação de controle compartilhado com acionistas privados, ou de participação minoritária com prerrogativas estratégicas". ${ }^{28}$

Bem de ver que a Lei Complementar no 101/2000 (LRF) traz definição de empresa controlada - sociedade cuja maioria do capital social com direito a voto pertença, direta ou indiretamente, a ente da Federação -, mas cumpre destacar que tal regramento, consoante se infere do caput do art. 2o (o legislador usa a expressão "para os efeitos desta lei") - , é restrito ao objetivo de definir o grau de submissão dessas empresas aos ditames da LRF, não servindo, tout court, para descaracterizar as definições e conceitos gerais do direito empresarial previstas, por exemplo, na Lei n⿳ำ 6.404/1976.

Nos termos comumente propostos, são empresas controladas diretamente pelo poder público aquelas em que o Estado (leia-se administração direta) dispõe da maioria das ações com direito a voto (controle acionário majoritário), ao passo que são empresas controladas indiretamente pelo poder público aquelas em que o controle majoritário encontra-se nas mãos de entidade da administração indireta ou de holding estatal ${ }^{29}$ destinada a congregar participações majoritárias no capital de outras empresas. ${ }^{30}$

Pinto Júnior, Empresa estatal, op. cit., p. 126.

28 Ibid., p. 126, n. 101.

29 Pedro Paulo de Almeida Dutra defende a aplicação do modelo de holding para definir a política setorial e coordenar a execução pelo conjunto de empresas sob seu controle, nos seguintes termos: "A empresa holding terá o encargo de estabelecer as relações entre as empresas do sistema e o Governo, a nível de supervisão ministerial. Ela o fará como um interlocutor privilegiado; por um lado, a própria natureza lhe assegurará a sensibilidade suficiente para melhor compreender o jogo econômico, as restrições que ele impõe e as necessidades reais 
Com efeito, leciona Sérgio de Andrea Ferreira que:

O poder público pode preferir, ao invés de instituir ou constituir empresas administrativas, integrantes da administração indireta e, desse modo, componentes da organização governamental, criar, em cooperação com particulares, empresas que sejam instrumentos de participação pública na economia, mas sem a natureza de pessoas administrativas. São empresas dessa nova espécie, de Direito Privado, mas tipicamente paradministrativas, pois que situadas fora da administração pública, embora com elas relacionada. ${ }^{31}$

Como se vê, as empresas ditas controladas pelo poder público não podem, em sentido estrito, ser consideradas sociedades de economia mista ${ }^{32}$ (diante da ausência de requisitos legais mínimos para a sua formação, exigidos pelo art. 5o do Decreto-Lei no 200/1967), tampouco como integrantes da administração indireta (a despeito da posição do TCU). Assim, a respectiva submissão às normas de funcionamento das demais empresas privadas impõe, em matéria de controle societário, por exemplo, perscrutar os requisitos exigidos pela legislação societária (ressalvadas aquelas empresas submetidas aos ditames da LRF). ${ }^{33}$

das empresas; de outro, a relação com o Ministro encarregado da supervisão se estabelecerá de um modo totalmente diferente, uma vez que ele representa todo um setor de atividade industrial, e não uma só empresa" (DUTRA, Pedro Paulo de Almeida. Controle de empresas estatais. São Paulo: Saraiva, 1991. p. 185).

30 A experiência brasileira oferece bons exemplos de utilização do formato holding para agrupar empresas de um mesmo setor produtivo, como foi o caso da Rede Ferroviária Federal S/A, Eletrobras, Telebras, Siderbras, atualmente o caso da Cemig.

31 FERREIRA, Sérgio de Andrea. Comentários à Constituição. Rio de Janeiro: Freitas Bastos, 1991. v. 3, p. 268 (grifos nossos).

32 Sobre o tema, o STF, no julgamento do RMS 24.249/DF, rel. min. Eros Grau, registrou que “(...) dever-se-ia conceber o conceito de sociedade de economia mista em termos amplos, considerando-se como tal aquela, anônima ou não, sob o controle da União, dos Estadosmembros, do Distrito Federal ou dos Municípios, independentemente da circunstância de ter sido ou não criada por lei...". Em rumo diverso do julgado, a proposição deste trabalho é, a exemplo das disposições da Lei de Responsabilidade Fiscal, considerar a sociedade de economia mista como espécie do gênero entidades controladas pelo poder público e não o inverso.

33 Tais empresas encontram-se estando sujeitas à falência e à liquidação sem privilégios art. 235, §2º, da Lei ํo 6.404/1976. Suas ações ou títulos são bens móveis da administração e, após avaliados, podem ser alienados até mesmo sem licitação (art. 17, II, c, d, e e, da Lei no 8.666/1993), mas em se tratando de companhia aberta, a alienação do controle dependerá de prévia autorização da Comissão de Valores Mobiliários (art. 254, Lei no 6.404/1976).

34 Carlos Ari Sundfeld e Rodrigo Pagani de Souza defendem a possibilidade de substituição do clássico sistema de subvenções econômicas (art. 18 da Lei no 4.320/1964) por outro sistema 


\section{Logo, será imprescindível verificar amiúde a forma de estruturação e} os demais atos constitutivos da empresa controlada, bem como seu status de governança corporativa. É que não se compreende como configurado o poder de controle quando substancialmente ausentes as prerrogativas exigidas pela legislação societária (preponderância nas deliberações da assembleia geral e poder de eleger a maioria dos administradores da companhia, aliados ao usufruto efetivo do poder de controle sobre a empresa). E uma vez inexistentes os requisitos, a entidade sequer poderá ser inserida no gênero "controlada" (direta ou indiretamente), devendo ser enquadrada na categoria de "empresa participada".

Na mesma linha de argumentação, não se pode ignorar que, pela via do acordo de acionistas - instrumento previsto nos arts. $116^{35}$ e $118^{36}$ da Lei de Sociedades Anônimas e que compreende atos de aquisição e manutenção do controle societário-, é possível que o poder público, ainda que com número inferior ou igualitário de ações com direito a voto, disponha sobre sua interferência ou saída em decisões estratégicas da controlada, fundamentalmente diante de contingências de governança, econômicas e de mercado e vice-versa. ${ }^{37}$

Diz-se vice-versa porque nas empresas controladas pelo poder público, diferentemente das sociedades de economia mista - em que o Decreto-Lei no 200/1967 exige, para a manutenção da respectiva natureza jurídica, que a

remuneratório, vinculado à efetiva prestação de serviços aos usuários, como forma de descaracterizar a condição de empresa estatal dependente (art. 2으. III, da LRF). Vale dizer que, mediante contrato, para estes autores, é possível flexibilizar a condição de empresa estatal dependente (SUNDFELD, Carlos Ari; PAGANI DE SOUZA, Rodrigo. A superação da condição de empresa estatal dependente. Revista de Direito Público da Economia, Belo Horizonte, n. 12, p. 9-50, 2006).

35 "Art. 116. Entende-se por acionista controlador a pessoa, natural ou jurídica, ou o grupo de pessoas vinculadas por acordo de voto, ou sob controle comum, que: a) é titular de direitos de sócio que lhe assegurem, de modo permanente, a maioria dos votos nas deliberações da assembleia-geral e o poder de eleger a maioria dos administradores da companhia; e b) usa efetivamente seu poder para dirigir as atividades sociais e orientar o funcionamento dos órgãos da companhia."

36 "Art. 118. Os acordos de acionistas, sobre a compra e venda de suas ações, preferência para adquiri-las, exercício do direito a voto, ou do poder de controle deverão ser observados pela companhia quando arquivados na sua sede".

37 "Não é incompatível com a noção de sociedade de economia mista que haja controle conjunto com sujeitos privados. Assim, é perfeitamente válido que o Estado promova acordo de acionistas com um ou mais particulares, disciplinando o exercício do direito de voto. O fundamental será que esse acordo de acionistas resulte não na eliminação do poder de o Estado eleger a maioria dos diretores ou a imposição de orientação ao funcionamento dos órgãos societários." (JUSTEN FILHO, Marçal. Curso de direito administrativo. 2. ed. São Paulo: Saraiva, 2006. p. 128) 
maioria do capital com direito a voto esteja nas mãos do poder público (o que somente pode ser alterado por lei específica: art. 37, XIX, CR), não se vislumbra impeditivo a que também pela via do acordo de acionistas haja o compartilhamento do controle entre o sócio público e o privado, mecanismo que alteraria temporariamente o enquadramento da empresa.

Isso porque o art. 118 da Lei de Sociedades Anônimas serve ao desiderato de cumprir a exigência do art. 37, XX, da CR/88 (trata-se de autorização legislativa genérica) para disciplinar a participação do poder público na constituição da empresa, podendo seus administradores, por atos volitivos e de governança corporativa, compartilhar as decisões estratégicas com os sócios particulares, provocando a diluição do controle societário.

Conforme Mário Engler Pinto Júnior,

(...) admite-se hoje que a fórmula contratual então recomendada encontra-se superada para modular a atuação das empresas estatais que deixaram de ser monopolistas e passaram a concorrer com o setor privado. Nesse caso, a tendência atual inclina-se pelo modelo da governança corporativa que valoriza as instâncias internas da companhia para definir objetivos, eleger estratégias e monitorar o desempenho empresarial, com a consequente diluição da figura da tutela administrativa. O raciocínio faz todo sentido em relação às empresas estatais regidas pela lei do acionariato, que disciplina minuciosamente as competências e responsabilidades dos órgãos de administração, bem como o processo decisório no interior da sociedade. Em relação às autarquias e fundações governamentais, a contratualização do relacionamento continua sendo instrumento extremamente útil em termos de gestão pública. $^{38}$

$\mathrm{O}$ acordo de acionistas na proposta que se apresenta funcionaria como ato condição para o desencadeamento, a tempo certo, de um novo regime jurídico (em configuração parelha, porém mais avançada, do que o contrato de gestão ou de autonomia, ${ }^{39}$ previsto no art. $37, \S 8^{\circ}$ da $\mathrm{CR} / 88$, e vocacionado para as entidades da administração indireta e órgãos da administração

38 Pinto Júnior, Empresa estatal, op. cit., p. 135.

39 O contrato de gestão que é originário da experiência francesa com o Relatório Nora de 1967 sobre a relação entre o poder central e as empresas estatais francesas. 
direta), regime este tipicamente de direito privado, mais flexível, e que haverá de ser aplicável à entidade por prazo determinado, aproximando-a do regime jurídico das empresas participadas. ${ }^{40} 41$

\subsection{Empresas participadas (participação minoritária ou paritária do poder público)}

A participação minoritária ou paritária do Poder Público - direta ou indiretamente - na formação do capital de empresas privadas, bem como a paridade ou inferioridade de sua participação nos aspectos relativos ao controle cumprem função básica de apoiar o empreendimento privado em setores-chave da economia nacional, podendo vir acompanhada de poderes limitados (e não preponderantes) de ingerência na condução dos negócios

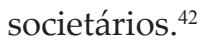

Nesse tipo de formato empresarial, também se verificam situações em que o exercício, pelo Estado, da posição de acionista não controlador é utilizado para assegurar a preservação de interesses estratégicos de empresas privatizadas. De igual modo, é comum que o Estado utilize como veículo do investimento acionário alguma agência especializada pública ou sociedade holding integrante da administração pública.

40 É preciso superar a noção antiquada de que o controle de entidades de que o Estado participe só se tornará efetivo com instrumentos típicos de administração burocrática e de direito público. "A solução para os dilemas que afligem o controle governamental pressupõe a valorização do papel dos conselhos de administração e fiscal da empresa estatal, que devem ser integrados por pessoas profissionalmente competentes e comprometidos com a causa pública." (Pinto Júnior, Empresa estatal, op. cit., p. 137, n. 127). Não vejo sequer impossibilidade de os órgãos de tutela ou de controle externo (TCU) indicarem membros seus para participarem (em acompanhamento) das deliberações desses órgãos internos da entidade.

41 Desataca-se, desde já, que o mecanismo pode vir a ser previsto em Decreto (art. 84, IV, CR/88), que venha a regulamentar o art. 118 da Lei de Sociedades Anônimas, a fim de uniformizar o emprego do acordo de acionistas (ato regra) pelas entidades administrativas.

42 Nas lições de Arnold Wald, essa modalidade de investimento estatal é alternativa mais inteligente ao simples subvencionamento de empresa privada. Para ele, "nas sociedades em que o Estado é minoritário, a participação pública veio substituir vantajosamente o antigo sistema de subvenções. Os poderes públicos, operando para incentivar a produção nacional, especialmente nos países subdesenvolvidos, que se caracterizam pela falta de capitais particulares vultosos, preferiram a técnica da sociedade de economia mista com participação minoritária à subvenção, já que na mesma empresa mista, o Estado tem maior controle e conhecimento direto das atividades sociais, evitando assim que fundos públicos sejam utilizados de modo diverso ou contrário à finalidade a que se destinavam." (WALD, Arnold. As sociedades de economia mista e as empresas públicas no direito comparado. Revista Forense, v. 152, p. 513, 954). Observe que o autor fala em "sociedade de economia com participação minoritária", equivalente à figura intitulada aqui "entidade ou sociedade participada". 
Em quaisquer das situações subsiste o caráter privatista da empresa participada, que se apresenta desvinculada das injunções publicísticas, mesmo que haja a dependência de autorização legislativa para a participação estatal na conformação da entidade (art. 37, XX, CR/88).

Sobre este tipo de entidade, vale citar a disposição do art. 9o , §4ํำ da Lei de Parcerias Público-Privadas (Lei no 11.079/2004), que veda a detenção da maioria do capital com direito a voto em eventual sociedade de propósito específico constituída com participação estatal, para o desempenho e execução do contrato de PPP.

Também o disposto no art. 5ํ da Lei de Inovação Tecnológica (Lei no $10.973 / 2004$ ), que prevê a possibilidade de participação minoritária da União e de suas entidades da administração indireta no capital de empresa privada de propósito específico que vise ao desenvolvimento de projetos científicos ou tecnológicos para a obtenção de produtos ou processos inovadores. ${ }^{43}$

Nas entidades participadas, a despeito da prevalência constitutiva da participação acionária privada, também será imprescindível análise efetiva da repartição do poder de controle, porquanto a substancial (e não apenas formal) prevalência do poder público nas deliberações societárias (por acordo de acionistas, por exemplo), em sentido inverso ao que se afirmou no item precedente, pode ter o reflexo de lhe atrair a condição de empresa controlada (art. 118 da Lei das S.A.), e consequentemente, nalguns pontos (previstos em lei), lhe imprimir regime jurídico derrogatório do direito privado.

\section{Conclusão}

A dinamicidade do universo corporativo impõe um novo olhar sobre as formas de relacionamento entre os setores público e privado, introduzindo

43 O Decreto no 5.563/2005 (art. 5o), ao regulamentar o preceito da lei de inovação, dispõe que a União e suas entidades poderão participar de SPE que vise ao desenvolvimento de projetos científicos ou tecnológicos para obtenção de produto ou processo inovadores, desde que haja previsão orçamentária e autorização do presidente da República. Dito preceito merece ser interpretado com ressalvas. Primeiro porque a previsão orçamentária somente será necessária se a participação da União ou de suas entidades implicar a geração de despesas públicas, em virtude do conteúdo típico da lei orçamentária, que é basicamente restrito à previsão de receitas e despesas (art. 165, §8o da Constituição). Segundo porque a autorização do presidente da República tem sentido no âmbito da administração direta, submetida ao princípio da hierarquia, mas não no das entidades da administração indireta, cuja autonomia administrativa, financeira e orçamentária e o vínculo de supervisão e tutela (e não de hierarquia) com o poder central afastam a necessidade dessa autorização. 
- no cenário empresarial de que o Estado participa - arranjos societários capazes de substituir, com vigor, aqueles tradicionalmente existentes.

A noção de poliformismo organizatório, trabalhada pela doutrina alienígena - e objeto de textos fragmentários e de decisões judicias não sistematizadas no Brasil — , revela a possibilidade de o poder público atuar sob diferentes formatos (administração direta, autarquias, fundações, sociedades mistas, empresas públicas) em diversos tipos de atividades (atividade econômica, serviços públicos, fomento, fiscalização), sem que para tanto se reconheça um perfeito enquadramento das estruturas respectivas nos conceitos gerais e abstratos traçados pelo legislador do Decreto-Lei no 200/1967.

Na seara empresarial, a mescla de participação estatal e privada, além das sociedades de economia mista, admite também a conformação de empresas controladas (nas quais se incluem as empresas subsidiárias) e empresas participadas. E tais empresas não integram a administração indireta (diferentemente das sociedades de economia mista) e regem-se pelo direito privado.

As empresas participadas não geram muita polêmica porque a participação estatal nelas é minoritária. Já as controladas atraem considerável nível de debate, justificando neste ensaio maior detalhamento e vagar, bem como propostas para uma maior flexibilidade de atuação.

Tal debate gira em torno do grau de publicização do regime privado nas empresas controladas pelo poder público, reconhendo-se-lhes não raro o mesmo tratamento das sociedades de economia mista, notadamente a partir de dois aspectos: a) predominância formal do capital societário estatal; b) definição de "empresa controlada" da Lei de Responsabilidade Fiscal (art. 2으, III).

O raciocínio é exagerado. Primeiro: porque as controladas não integram a administração indireta e não podem ser tratadas como se efetivamente integrassem; segundo: porque as definições sobre o controle societário no âmbito dessas entidades devem ser feitas à luz do que preceitua a Lei no 6.404/1976, que exige mais do que a predominância formal do capital para que o controle efetivamente se configure, pelo menos quando não se trate de empresas dependentes; terceiro: porque a estas (dependentes) devem ser aplicadas as definições da LRF (art. 2º, III), escapando do conceito as controladas que não recebam subvenções econômicas do tesouro para despesas de capital ou de custeio em geral.

Assim, será necessário analisar amiúde a conformação do capital da empresa, a existência ou não de acordos de acionistas, o poder de direção efetivamente exercido e a prerrogativa de eleger a maioria dos administradores da 
companhia, tudo para efeito de definir se efetivamente se trata de empresa controlada. Só aí deve-se partir para elucrubações sobre o regime jurídico que lhes é aplicável (momento em que o poliformismo se manifestará uma vez mais). Mesmo assim - convém esclarecer - a sujeição às normas publicísticas apenas ocorrerá nas hipóteses expressamente previstas no ordenamento jurídico (v.g., art. 1o, parágrafo único da Lei no 8.666/1993) e não em todos os casos.

A despeito disso, o atual marco da governança coorporativa no Brasil permite que o enquadramento e, por consequência, o regime jurídico dessas entidades sejam dinamizados, podendo sofrer alterações temporárias a partir da celebração de acordos de acionistas (ato condição), que encontra amparo no art. 118 da Lei de Sociedade Anônima (Lei no 6.404/1976). Este acordo pode diluir temporariamente o controle da empresa, fazendo com que ela deixe de se enquadrar (durante o prazo nele determinado) na categoria das controladas, passando à das participadas (integralmente submetidas ao direito privado) situação que deve ser monitorada e renovada e revista sempre que se fizer necessário, conforme deliberações societárias.

Obviamente, o êxito da implementação dessas novas parcerias societárias pressupõe que os órgõas de controle, notadamente o Tribunal de Contas e o Ministério Público, substituam os critérios estritamente formais de controle por critérios de índole teleológica, creditando e impulsionando instâncias internas de governança dessas sociedades. Pressupõe que o controle seja voltado à atuação global da entidade, de acordo com o planejamento governamental, sem que se transformem em mecanismos espúrios de aparelhamento particular do Estado.

A busca também de um melhor tratamento legislativo quanto ao tema poderia auxiliar, com o predicado da brevidade, na mudança dessa forma encravada e unívoca de controlar os estamentos públicos, fundamentalmente os empresariais. Por isso, rendem-se homenagens à proposta de anteprojeto de lei sobre organização administrativa brasileira, que disciplinou a possibilidade de conformação de diversas empresas ou entidades com participação estatal que não integram a administração indireta, preconizando-lhes regimes jurídicos adequados às finalidades. ${ }^{44}$

44 "Art. 10. As entidades estatais podem: I - participar, quando autorizadas por lei específica, do capital de empresa não estatal, desde que isso não lhes confira, de modo permanente, preponderância nas deliberações sociais ou poder para eleger a maioria dos administradores; II - participar, quando autorizadas por lei específica, do capital e do controle de empresas constituídas fora do território nacional, sob a égide de legislação estrangeira; III - participar, 
Como dizia Derbalay: "Ce n'est pas en livrant des combats de retardement pour maintenir un état de chose révolu qu'on résoudra les problèms de notre époque" ${ }^{45}$

\section{Referências}

BORBA, José Edwaldo Tavares. Direito societário. 6. ed. Rio de Janeiro: Renovar, 2001.

COMPARATO, Fábio Konder; SALOMÃO FILHO, Calixto. O poder de controle na sociedade anônima. 5. ed. Rio de Janeiro: Forense, 2008.

CORREAA-LIMA, Osmar Brina. Sociedade anônima. 3. ed. Belo Horizonte: Del Rey, 2005.

CRETELLA JÚNIOR, José. Dicionário de direito administrativo. Rio de Janeiro: Forense, 1978.

DARBELAY, Jean. Vers la revision de la constitution fédérale. Revue de Droit Suisse, v. 87, p. 425-437, 1968.

DUTRA, Pedro Paulo de Almeida. Controle de empresas estatais. São Paulo: Saraiva, 1991.

FERRAZ, Luciano. Principais apontamentos acerca das sociedades de economia mista. Revista do Tribunal de Contas de Portugal, Lisboa, n. 26, p. 301-319, jul./dez. 1996.

FERREIRA, Sérgio de Andrea. Comentários à Constituição. Rio de Janeiro: Freitas Bastos, 1991. v. 3.

FORSTHOFF, Ernst. Lehrbruch des Verwaltungsrecht. I Band. Munique: Beck, 1961.

como patrocinadoras, de entidades fechadas de previdência complementar, na forma do art. 202 da Constituição e da lei complementar; IV - manter vínculo de colaboração com entidade não estatal de direito privado sem fins lucrativos, por meio de contrato público de colaboração, na forma desta Lei. §1ㅇ A União pode participar, de forma direta ou indireta, do capital de empresa supranacional, nos termos do tratado constitutivo. $2^{\circ}$ As empresas ou entidades com participação estatal a que se refere este artigo não integram a administração indireta e estão sujeitas ao regime jurídico que lhes é próprio, segundo sua legislação de regência, não lhes sendo aplicáveis o regime e os controles a que se submetem as entidades estatais."

45 DARBELAY, Jean. Vers la revision de la constitution fédérale. Revue de Droit Suisse, v. 87, p. 425-437, 1968. Traduzindo: “o que importa é não perder tempo em puros combates de retardamento, para manter um estado de coisas do passado, com o que não se resolverão os problemas do nosso tempo". 
JUSTEN FILHO, Marçal. Comentários à Lei de Licitações e Contratos Administrativos. 14. ed. São Paulo: Dialética, 2009.

JUSTEN FILHO, Marçal. Curso de direito administrativo. 2. ed. São Paulo: Saraiva, 2006.

MOREIRA, Vital. Administração autónoma e associações públicas. Coimbra: Almedina, 1997.

ORTIZ, Gaspar Ariño. De la empresa publica a la empresa con participación pública. Revista de Administración Pública, n. 138, p. 7-36, 1995.

OTERO, Paulo. Vinculação e liberdade de conformação do setor empresarial do Estado. Coimbra: Coimbra Editora, 1998.

PINTO JÚNIOR, Mário Egler. Empresa estatal: função econômica e dilemas societários. 2. ed. São Paulo: Atlas, 2013.

SHOLZ, R. Kriterien für die Wahl der Rechtsform. Handbuch der Kommunalen Wissenschaft und Praxis. Springer Verlag, 8 Auf.

SUNDFELD, Carlos Ari. Uma lei de normas gerais para organização administrativa brasileira: o regime jurídico comum das entidades estatais de direito privado. In: MODESTO, Paulo (Coord.). Nova organização administrativa brasileira. Estudos sobre a proposta da comissão de especialistas constituídas pelo Governo Federal para reforma da organização administrativa brasileira. 2. ed. Belo Horizonte: Fórum, 2010. p. 66-67.

; PAGANI DE SOUZA, Rodrigo. A superação da condição de empresa estatal dependente. Revista de Direito Público da Economia, Belo Horizonte, n. 12, p. 9-50, 2006.

TÁCITO, Caio. As empresas estatais no direito brasileiro. In: Temas de direito público. Rio de Janeiro: Renovar, 1997. v. 1.

WALD, Arnold. As sociedades de economia mista e as empresas públicas no direito comparado. Revista Forense, v. 152, mar./abr. 1954. 